\title{
(1) \\ A multivariate study of over-indebtedness' causes and consequences
}

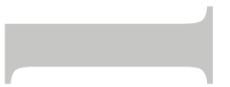

\author{
Begoña Gutiérrez-Nieto* \\ (corresponding author: bgn@unizar.es) \\ Carlos Serrano-Cinca* \\ Marta de la Cuesta $* *$ \\ * University of Zaragoza \\ Gran Vía 2, Zaragoza, Spain. \\ ** Universidad Nacional de Educación a Distancia (UNED) \\ Calle Juan del Rosal, 14, Madrid, Spain.
}

Acknowledgments: This work was supported by grant ECO2013-45568-R of the Spanish Ministry of Education, and the European Regional Development Fund and by grant Ref. S-14/2 of the Government of Aragon. The research team is grateful to the Spanish Mortgage Victims Platform for its collaboration.

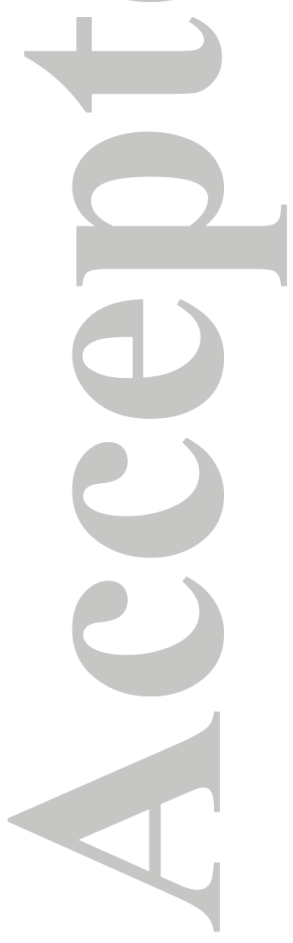

Please cite this article as an 'Accepted Article', doi: 10.1111/ijcs.12324 


\title{
A multivariate study of over-indebtedness' causes and consequences
}

\begin{abstract}
This paper proposes a comprehensive explanatory model to explain both causes and consequences of over-indebtedness. It presents as causes some borrower aspects, such as propensity to indebtedness and low financial literacy. Other causes are borrower circumstances: adverse external shocks, borrower internal problems and financial institutions' pressure. The model incorporates consequences on the borrower, the lender and the society. The model has been tested with a survey filled in by experts and over-indebted individuals. Results have been analyzed using multivariate techniques, including canonical correlations. There are differences in the opinions of experts and individuals: the latter blame external shocks or financial institutions' pressure, while the former find relevant factors the financial illiteracy or the tendency to imitate others. Experts and individuals agree on the consequences: poverty growth in the society and declining borrower's welfare. The paper concludes with the need to improve financial literacy, especially in the risks involved in over-indebtedness.
\end{abstract}

Keywords: Over-indebtedness, financial literacy, financial crisis, canonical correlations.

\section{Introduction}

An over-indebted household is defined as one whose existing and foreseeable resources are insufficient to meet its financial commitments without lowering its living standards (Brennan and Gallagher, 2007). Overindebtedness is a major problem that affects both borrowers and financial institutions, and even the whole society (European Commision, 2013). Over-indebtedness can be a major factor in creating poverty, particularly among low-income, old age households and single-parent households with young children (Betti et al, 2007). Besides, over-indebtedness can lead financial institutions to bankruptcy (Lascelles and Mendelson, 2012). Different authors have studied over-indebtedness under different approaches: drivers of over-indebtedness (Disney et al., 2008), the consequences of debt excess (Porter, 2012), the role of financial literacy (Gathergood, 2012), or psychological aspects (Lea et al, 1995). A number of empirical studies have been performed (Betti et al, 2007; Dickerson, 2008; and Schicks, 2014). Past research efforts are based on surveys which asked or experts or over-indebted individuals, but much can be learned by asking both experts and consumers, identifying differences between them. Although many studies analyze drivers and consequences of over-indebtedness, a comprehensive model is needed, relating both aspects, which motivates the present paper.

The first research question is to propose and test a model integrating both over-indebtedness causes and consequences, allowing us to study the relationship between them. Traditional theoretical models explaining over-indebtedness were based on economic theory and hypotheses on the rationale of decision makers, such as 
the Life-Cycle-Permanent Income theory (Ando and Modigliani, 1963). More recent models are improved by psychological theories, linked to behavioral economics (Loewenstein et al., 2003). This paper follows the rationalism and behaviorism philosophy by Ortega-y-Gasset (1961) proposing two kinds of causes: those linked to the individual, such as the lack of financial literacy or his willingness to be in debt; and those based on circumstances, such as external crises or the pressure put on by financial institutions. The consequences include the effect on individuals, financial entities and the whole of society. This is a holistic framework, integrating most of the causes and consequences mentioned in over-indebtedness literature. Most of the studies on overindebtedness are based on regressions, taking a measure of indebtedness as a dependent variable (Schicks, 2014). The statistical technique used in this paper is canonical correlations, a technique suitable for a set of independent variables (causes) and a set of dependent variables (consequences). To the best of our knowledge, there are no previous studies like the one presented here, which constitutes a contribution to the literature.

The second research question is to identify the causes and consequences of over-indebtedness which are more important. Most of the studies survey individuals (Betti et al 2007; Gathergood, 2012; and Schicks, 2014), but some of them survey experts (Kilborn, 2011). The study also aims at identifying different perceptions in overindebtedness consequences among individuals and experts. The same survey has been filled in by a sample of individuals and a sample of experts, and it has been analyzed using different methodologies, including a means test and multivariate techniques. This is another contribution of this study.

The empirical study has been performed in Spain, where the financial crisis hit hard, with a high number of people who cannot meet their financial commitments. Overindebtedness from mortgages was considered one of the main troubles for Spaniards (Martín and García, 2016). The financial crisis provoked the rescue of the damaged banking sector, the credit tap being turned off, and housing evictions enforced. There have even been political consequences: the founder of the Spanish Mortgage Victims Platform has been recently elected as mayor of Barcelona. Differences are found in the opinions of experts and individuals. Individuals blame external shocks or financial institutions' pressure, while they find financial illiteracy or financial attitudes less important than experts do. Impoverishment in society and worsened individual welfare are the more remarkable overindebtedness consequences, among the data analyzed. The diagnosis of the consequences is similar for experts and individuals.

The remainder of the paper is organized as follows. Section 2 presents the literature review and hypothesis development. Section 3 presents the empirical study. Finally, conclusions are presented.

\section{Literature review and hypothesis development}

A number of economic theories explain over-indebtedness. The Life-Cycle-Permanent Income theory analyzes the spending and saving habits of people over their life arguing that individuals choose to maintain stable lifestyles 
(Ando and Modigliani, 1963). Indebtedness is a planned and rational decision that allows inter-temporal redistribution of consumption. The Behavioral-Life-Cycle theory theory affirms that individuals often do not think about spending and loan decisions using discount rates, but through mental accounting - the real way people treat financial events (Shefrin and Thaler, 1988). This way consumption plans are affected by a lack of self-control, usually ignored in economic analysis, which really influence human behavior.

Behavioral approaches have become one of the mainstream approaches to explain over-indebtedness, supported by the research of psychologists. According to the Projection Bias theory, people tend to underappreciate the effects of changes in their states, and hence falsely project their current preferences over consumption into their future preferences (Loewenstein et al., 2003). Prospect theory concludes that people are not consistently risk-averse: they are risk-averse in gains but risk-takers in losses (Kahneman and Tversky, 1979), which can explain over-indebtedness. Several studies have found that people tend to overestimate the precision of their knowledge, generating overconfidence and debt (Bird et al, 2014).

The theory of decision making has become a meeting place for psychological and economic theory (Simon, 1956). The conceptual framework of our paper is rooted in both behaviorism and rationalism. The proposed model (Figure 1) follows Ortega-y-Gasset (1961) formula: "I am myself plus my circumstance”. Circumstance includes material things, people, society, and culture. Some circumstances favor over-indebtedness, such as the external pressure by financial institutions, or the environment that pushes people towards debt. This situation can be worsened by external factors, such as country general crises or unexpected personal situations, such as unemployment. As for the individuals, some of them can have a propensity for debt and an inadequate perception of risk. The lack of financial literacy is also associated to over-indebtedness. As for overindebtedness consequences, the effects on debtors, financial institutions and society are remarkable. The borrower is affected in psychological and material aspects. The lender is affected by write-offs that worsen its financial performance; and it also suffers from reputational losses. The whole of society can receive a negative impact from an economic point of view, as well as from low social cohesion and high poverty levels.

\section{[Figure_1]}

\section{External adverse shocks}

Unexpected macroeconomic shocks are a major driver of over-indebtedness according to the Life-CyclePermanent Income theory (Betti et al, 2007). In fact, the only explanation of over-indebtedness that is consistent with this rational model is unexpected adverse shocks to the consumer's expenditure requirements. The institutional and legal environment can increase or reduce the risks of over-indebtedness (Schicks 2014). For example, in the Spanish case, non-recourse debt does not exist, so if the borrower defaults, the fact of giving the house back to the bank does not cancel the debt. 
An important aspect is the growing importance of external factors as over-indebtedness drivers, in detriment of recognizing debtors' own responsibilities. In a study about popular media, representations of debtors from the last 150 years indicated that popular culture has changed, with people coming to see debt problems not as resulting from moral depravity but as understandable caused by external factors such as market shifts, unemployment, illness, and so on (Efrat, 2006). Another study indicated that structural conditions such as financial deregulation or aggressive marketing banking campaigns lead to a culture hospitable to over-indebtedness (Braucher, 2006).

\section{Internal adverse shocks}

Income falls due to negative personal circumstances, such as unemployment, illness or unexpected expenses may cause over-indebtedness (Gathergood, 2012; Kempson, 2002). Internal structural factors include family break-up and a lack of health insurance (Braucher, 2006). The Life-Cycle-Permanent Income theory supports this reasoning: although the presence of mechanisms to cover these critical incidents, such as insurance, social safety networks or family support, such mechanisms do not always work and over-indebtedness can arise (Betti et al. 2007). Kamleitner and Kirchler (2007) review the literature on critical life events causing over-indebtedness, concluding that over-indebtedness is mainly determined by financially relevant life events such as job loss or divorce.

\section{Financial institutions' pressure}

Different situations favor the idea of considering financial entities as drivers of over-indebtedness. During the expansionary phase of a cycle, banks' lending standards are relaxed and bad loans could probably be allocated (Dell'Ariccia and Marquez, 2006). These authors present a theoretical model that provides an explanation for the following sequence: financial liberalization, lending booms, and banking crises. Their model can also explain why financially excluded people have moved from the lack of credit to over-indebtedness. Lascelles and Mendelson (2012) and Garðarsdóttir and Dittmar (2012) directly blame financial institutions of competitive pressure leading to irresponsible lending and over-indebtedness. Braucher (2006) highlights the lack of financial regulation and creditors' sophisticated marketing, and high-pressure loan collection techniques. Another study finds evidence of irresponsible lending practices associated with over-indebtedness by offering low initial interest rates and higher credit limits (Kempson, 2002).

\section{Financial illiteracy}

The low financial literacy level, the lack of abilities and the lack of experience to manage money are proposed as over-indebtedeness drivers in the literature (Disney et al. 2008, Townley-Jones et al. 2008, Agnew and CameronAgnew 2015). Both the Consumption Function theory (Friedman, 1957) and the Life-Cycle-Permanent Income theory (Ando and Modigliani, 1963) have been used as a theoretical support. These economic theories state that a wellinformed individual will consume less than his income in times of high earnings, with the aim of supporting 
consumption when income falls. A bad-informed individual will take wrong decisions, one of them, incurring debt beyond his means.

The relationship between illiteracy and over-indebtedness has been empirically tested in several studies. Illiterate people do not only take on loans beyond their means, but also they pay more (Disney and Gathergood, 2013). An empirical study that includes economic, educative and psychological variables finds that poor money management seems to be especially important (Lea el al, 1995). However, another study finds that financial literacy is a secondary concern when it comes to decision making (Hung et al., 2009).

\section{Propensity to indebtedness}

Tendency to imitate others overlooking the risks involved in lending, and borrowers' materialism are financial attitudes that derive partially from each one's underlying preferences. Behavioural Economics and Psychology go beyond economic theories and identify several bias, such as an overconfidence bias, intertemporal balancing of utility, locus of control, or habit persistence, among others (Schicks, 2014). The Prospect theory (Kahneman and Tversky, 1979) help to explain behaviors such as addiction to and excessive pursuit of a high material standard of living; and they can also explain over-borrowing. Over-indebtedness occurs more frequently among individuals who report self-control problems, who are also more likely to suffer adverse financial shocks (Gathergood, 2012). There is a clear evidence of borrowers acting irresponsibly: they borrow money when experiencing financial difficulties to pay off other credits or other commitments (Kempson, 2002).

A person with high materialistic values believes that the acquisition of material goods is a main life goal. Materialism is a stronger predictor of the amount of debt instead of income or money-management skills (Garðarsdóttir and Dittmar, 2012). In a study about the role of social support for debt, an important factor in predicting debt status was whether individuals knew other people around them who were in debt (Lea et al., 1995). In other cases, the family context influences financial attitudes, finding that people's information on how their parents use credit correlated with their own ability to use credit successfully (Tokunaga, 1993).

\section{Consequences on borrowers}

There are economic consequences of over-indebtedness, such as lower consumption level (Betti et al., 2007), or sacrifices even reducing basic consumer goods (Brett, 2006) that can lead to poverty (Kempson, 2002 and Porter, 2012). A deteriorated credit history can imply complete exclusion from credit (Lyons and Fisher, 2006). There are also psychological effects, such as a fear of regret, the distress for having made errors and the mental suffering experienced facing the evidence that beliefs have been wrong (Shiller, 1995). Financial difficulties drive to family conflicts that, in cases of delinquency and default, are more harmful (Kempson, 2002). Over-indebtedness represents a principle of social exclusion that can lead to loss of reputation, humiliation, and in extreme cases, into suicide (Schicks 2014).

\section{Consequences on financial institutions}


Consequences on financial institutions have both an economic and an intangible nature. Borrower's overindebtedness affects lenders when it reaches the stage of delinquency. Financial institutions not only get less profit, but they also increase their probability of default. Empirical studies provide some support for the view that faster loan growth leads to higher loan losses (Serrano-Cinca et al., 2014). It has been so since the origins of banking: the failure of the powerful Florentine banks in the 14th century was caused by overextension of credit (De Roover, 1963).

The risk of default can potentially reduce financial system stability and can have a contagious effect among other banks. There is also a loss of reputation in the banking industry, which is very important since this business is based on depositors' trust, and a loss of reputation can lead to a panic run. A clear case of reputation losses happened in the microfinance industry: since over-indebted borrowers do not pay back, microfinance institutions drifted from their social mission, and charged high interest rates (Schicks, 2014).

\section{Consequences on the society}

Over-indebtedness can lead to important negative effects on the whole of society, such as poverty growth, low social cohesion, loss of confidence in the financial industry and reductions in the loan offer, even for solvent borrowers. Over-indebtedness leads to social exclusion, because debt burdens may inhibit the consumption that is often a required component in everyday social activities (Porter, 2012). The stigma of over-indebtedness may eventually affect, not only the delinquent borrower, but it also reduces social trust and mutual support in the community, eroding social networks (Schicks, 2014).

\section{Empirical study}

The empirical study is based in Spain, one of the countries where the 2008-2014 financial crisis hit more severely. According to the 2014 Survey on Living Conditions by the Spanish Statistical Office, 10.2\% of the Spanish households have experienced arrears in their payments related to their home, such as mortgage, rent, utility bills, or condo fees. According to the 2014 Survey on Migrations by the Spanish Statistical Office, the net balance from the beginning of the crisis was 524,880 Spanish persons leaving the country, contrasting with the net migration balance of 310,641 foreigners entering the country only in 2008. According to the Spanish Central Bank, the number of bank employees reduced from 278,301 in 2008 to 217,885 to 2013. In 2014, the country experienced some recovery, with a positive GNP growth.

The analysis was based on a survey to both experts and individuals. The experts' sample contains financial specialists from the academia and from the business sector. To build the individuals sample we contacted 3 consumer financial services associations, and one agreed to collaborate in the study: the Spanish Mortgage Victims Association. The individuals sample consists of people experiencing problems with their mortgage payments and under the threat of eviction. The surveys were filled in in November 2014 and the study was performed right afterwards. The sample has 122 surveys: 61 experts based and 61 individual based. 
Table 1 shows the survey items. They are 36 questions using a 7-point Likert scale. The questions' choice was based on the studies by Betti et al (2007), Gathergood (2012), Disney and Gathergood (2013), and Schicks (2014). Internal consistency was ensured by analyzing the relationships between each construct and its indicators. Content validity, unidimensionality, reliability, convergent validity and discriminant validity were ensured to assess psychometric properties for scales used in the study.

\section{[Table_1]}

Table 2 shows mean and standard deviation for both experts and individuals. An independent-samples ttest was conducted to compare experts' opinions to individuals' opinions. There are statistically significant differences. For individuals, the most important factor explaining over-indebtedness is external adverse shocks, such as an economic crisis, with an average of 6.03, facing an experts' average of 3.56. Differences were statistically significant. As for internal adverse shocks, such as unemployment or business closure, it is an important factor for individuals, 5.74, and less important for experts, 5.02. Differences were statistically significant. Financial institutions' pressure, especially in loan allocation for everyone, was considered an important factor for individuals, 5.82 and not so important for experts, 4.10. Differences were statistically significant. It can be interpreted that individuals blame circumstances more than experts do.

The opinions on the role played by financial literacy differ from individuals to experts. Experts find it an important over-indebtedness driver. This way, the lack of money management skills reaches a 5.07 for experts, while reaching a 4.05 for individuals. Differences were statistically significant. Propensity to over-indebtedness is an important driver and both groups agree. The idea that borrowers do not think about the risks involved in debt reaches a 5.56 for experts and 5.25 for individuals. Differences were not statistically significant. Differences arise in the tendency to imitate others: to have goods, to own a business or to be successful. This factor is considered more important for experts (5.25) than for individuals (4.00), and differences are statistically

significant. It can be interpreted that, assuming than experts' opinions are well rooted, individuals are not consistently assuming their part of the responsibility.

\section{[Table_2]}

Moving now to the consequences of over-indebtedness; poverty growth is remarkable both for experts (5.75) and individuals (5.98). Decline in welfare is 5.87 for experts and 5.31 for individuals. Differences are not statistically significant. However, differences in the opinions of experts and individuals are clear on the effect on the financial industry, especially on the way how financial services are offered: for experts the average is 5.48 and 4.74 for individuals. Differences were statistically significant. Experts warn of the loss of confidence in the financial industry (5.52) facing individuals (4.97), and differences were statistically significant. Experts highlight the deterioration of the mental health of borrowers (5.18) facing individuals (4.30). Differences were statistically 
significant. Deterioration of borrower welfare is more important for experts (5.87) than for individuals (5.31). Differences were statistically significant. Individuals are worried by the deterioration of basic daily aspects such as food or clothes (5.18) in a higher measure than experts (4.31). Differences were statistically significant.

A logistic regression analysis was conducted to test if there are global differences between individuals and experts' opinions. The regression takes as independent variables both causes and consequences. The dependent variable is a dummy variable that takes a 1 for experts and 0 for individuals. A test of the full model against a constant-only model was statistically significant, indicating that the predictors as a set reliably distinguished between experts and individuals (Chi square $=24.096$, $\mathrm{p}<0.000$ with $\mathrm{df}=2$ ). Nagelkerke's $\mathrm{R}^{2}$ of 0.737 indicated a moderately strong relationship between prediction and grouping. Prediction success overall was $90 \%$. Results on the discrimination power of each variable were coherent with univariate test results in Table 2. The most important differences between experts and individuals opinions are on the effect of economic crisis and on the pressure of financial institutions for giving loans to everyone. Both causes were previously identified as very important for individuals, and not so important for experts.

With the aim of understanding the analysis better, a Bi-Plot principal components analysis and a cluster analysis were conducted. Both analyses were performed independently: one for the causes and another one for the consequences. The robustness of the results of the data was assured by a bootstrap procedure applied to the component loadings. Additionally, several clustering algorithms were performed and results were very similar. Figure 2 represents the two principal components with Bi-Plot and also shows a dendrogram for the causes. The Bi-Plot allows information on both respondent and questions. Experts are represented as points, individuals are represented as crosses, while variables are displayed either as vectors. The first principal component accounts for $32.37 \%$ of the variance, and the second principal component accounts for $18.28 \%$. All the Bi-Plot vectors point out to the right, towards the first principal component, that is, all of them are over-indebtedness causes. The differences arise in the second principal component: the "circumstances" are on the top while the "me" is at the bottom, coherently with the proposed model. Figure 2 visualizes the differences between experts and individuals. Individuals are salient in the second principal component, in variables such as the crisis effect, the country unbalances, the financial institutions' pressure, and the unemployment. Experts, by contrast, are situated at the bottom, where variables such as financial literacy or attitudes facing debt point downwards. These results are coherent with the previous results by the means test. These results are also confirmed by the dendrogram obtained by the cluster analysis. Two groups of variables are clearly appreciated: a first cluster with the circumstances-related causes (external, internal and financial institutions' pressure) and a second cluster including the individual-related causes.

[Figure 2] 
Figure 3 shows the results of analyzing the consequences. The first principal component explains $43.87 \%$ of the variance, while the second principal component explains just a 9.48\%. The borrower related consequences are salient in the second principal component, whose vectors point towards the top; while the lender and society related consequences point towards the bottom. Not so many differences arise between experts and individuals. The dendrogram visualized the three clusters of consequences: borrower, financial sector and the whole society.

\section{[Figure 3]}

A canonical correlation analysis was conducted using the 18 cause's variables as predictors of the 18 consequence's variables to evaluate the multivariate shared relationship between the two variable sets. Table 3 shows the results. Four multivariate statistics (Pillai's trace, Wilks' lambda, Hotellings, and Roys) were performed to test the null hypothesis that the canonical correlations are zero. The full model across all functions was statistically significant according the four criteria, but only Wilks' lambda results were reported. Collectively, the full model across all functions was statistically significant using the Wilks's $\lambda=0.010$ criterion, $\mathrm{F}(324,1148.65)=1.558, \mathrm{p}<0.001$. Because Wilks's $\lambda$ represents the variance unexplained by the model, $1-\lambda$ yields the full model effect size in an $r^{2}$ metric. Thus, for the set of 18 canonical functions, the $r^{2}$ type effect size was 0.99. The two first canonical functions present eigenvalues higher than one, explaining a $24.51 \%$ and a $16.41 \%$ of the variance, respectively. In all, a $40.92 \%$ of the variance is explained. Squared canonical correlations $\left(R_{c}^{2}\right)$ for the two first function is 0.602 , and 0.503 respectively.

\section{[Table 3]}

These results confirm the relationship between the causes and consequences, and are coherent with previous studies. To measure the contribution of each variable to the model, the canonical communality coefficient (h2) has been calculated. It is the proportion of variance in each variable that is explained by the canonical functions that are relevant. The causal variables with a high explanatory power are the external circumstances, such as the growth in the country's unemployment $\left(h^{2}=54.18 \%\right)$, the economic crisis $\left(h^{2}=\right.$ $48.24 \%)$, and the pressure by loan officers $\left(h^{2}=35.09 \%\right)$. The consequences that contributed more to the model are the borrower's low self-esteem $\left(h^{2}=37.59 \%\right)$, the loss of reputation for financial institutions $\left(h^{2}=54.62 \%\right)$ and the loss of trust in the financial industry $\left(\mathrm{h}^{2}=45.78 \%\right)$.

Once the causes and consequences are identified, some policy recommendations can be drawn. A possible field is financial sector regulation. Dewatripont and Tirole (2012) analyze banking regulation in the presence of macroeconomic shocks, and affirm that policies are needed to validate managerial choices following good performance, while bad banking practices should be punished. In fact, some restructured Spanish banks accused of malpractice are still running. These regulatory changes should be accompanied by a set of incentives for loan officers, not based on the amount of loans allocated, but on the risk of these loans. These incentives should also include training 
to determine more precisely the borrower's repayment capacity. Strict limits on the maximum debt amount per borrower should be implemented, as well as clear rules for loan renewals. Experts' opinions suggest that borrowers' financial literacy should be improved and a cultural change would also be desirable to reduce the society materialism. With this aim, banking supervisors should monitor aggressive banking practices, as well as banking marketing campaigns. A gap between experts' and individuals' opinions exists and politic parties should be able to understand individuals' perceptions to meet voters. Finally, social financial institutions in developed countries should have a more relevant role, since they are now for a minority.

One of the study's limitations is that it relies on the sample size. The data analyzed in this study were collected without random selection. This study is working with perception-based data, which is less reliable in general than observable measures of the same constructs.

\section{Conclusions}

Over-indebtedness is a serious problem, with negative effects in borrowers, financial institutions and society. Its causes are explained with theories mixing the rationale inspired by economic theory, such as the LifeCycle-Permanent Income theory, with the behavioral inspired by psychology, such as the Projection Bias theory. This paper presents an over-indebtedness explanatory model which includes its causes and consequences, rooting in both rationalism and behaviorism. There is a continual interaction between the individual consumer and the person's circumstances, in such a way that each personal life results from an interaction between both factors. The causes analyzed are borrower aspects such as his propensity to indebtedness and his lack of financial literacy. It also includes as causes the borrower circumstances, such as adverse external shocks, borrower internal problems and the pressure of the financial industry. The model analyzes over-indebtedness consequences in the borrower, the lender and the society.

To test the model, a survey has been performed to both individuals and experts. The survey is based in Spain, a country who has suffered an important crisis based on a mortgage bubble. The technique used to analyze the data has been a means test to allow detecting differences between individuals and experts, as well as a logistic regression. A multivariate analysis using Bi-Plot principal components analysis and cluster analysis has enabled to have a global perspective of all the variables. Finally, the model has been estimated by means of canonical correlation analysis, because this technique can deal with a set of independent variables -causes- and a set of dependent variables -consequences-.

There are statistically significant differences between individuals and experts' opinions. The most important factors for individuals are their circumstances: external adverse shocks such as the economic crisis, internal adverse shocks such as unemployment, and financial institutions' pressure. By contrast, experts tend to blame the lack of financial literacy among individuals and the tendency to imitate others in their materialistic 
goals. It can be interpreted that, assuming than experts' opinions are well rooted, individuals are not consistently assuming their part of the responsibility. As for over-indebtedness consequences, both individuals and experts agree and rank high poverty growth and decline in welfare. Differences arise on the effect on the financial industry: experts warn of the loss of confidence in the financial industry. Individuals are concerned by the deterioration of basic daily consumption.

Some policy recommendations arise from the study in the fields of regulation and financial literacy. Changes in regulation would be necessary to support good banking practices, punishing malpractices which induce over-indebtedness. Finally, if the financial literacy of the population is improved, they will have more chances of dealing with over-indebtedness.

\section{References}

Agnew, S. \& Cameron-Agnew, T. (2015) The influence of consumer socialisation in the home on gender differences in financial literacy. International Journal of Consumer Studies, 39(6), 630-638

Ando, A., \& Modigliani, F. (1963) The "life cycle" hypothesis of saving: Aggregate implications and tests. The American Economic Review, 55-84.

Betti, G., Dourmashkin, N., Rossi, M., \& Ping Yin, Y. (2007) Consumer over-indebtedness in the EU: measurement and characteristics. Journal of Economic Studies, 34(2), 136-156.

Bird, C. L., Şener, A., Coşkuner, S. (2014) Visualizing financial success: planning is key. International Journal of Consumer Studies 38(6), 684-691

Braucher, J. (2006) Theories of overindebtedness: Interaction of structure and culture. Theoretical Inquiries in Law, 7(2), 323-346.

Brennan, C. Gallagher, K. (2007) Consumer overindebtedness: a review of the quality of money advice services in Scotland. International Journal of Consumer Studies 31(6), 623-629

Brett, J. A. (2006) "We Sacrifice and Eat Less": The Structural Complexities of Microfinance Participation. Human Organization, 65(1), 8-19

De Roover, R. (1963) The rise and decline of the Medici Bank, 1397-1494, Cambridge: Harvard University Press.

Dell'Ariccia, G., \& Marquez, R. (2006) Lending booms and lending standards. The Journal of Finance, 61(5), 25112546.

Dewatripont, M., \& Tirole, J. (2012) Macroeconomic shocks and banking regulation. Journal of Money, Credit and Banking, 44(s2), 237-254.

Dickerson, A. M. (2008) Consumer over-indebtedness: A US perspective. Texas International Law Journal, 43, 135. 
Disney, R., \& Gathergood, J. (2013) Financial literacy and consumer credit portfolios. Journal of Banking \& Finance, 37(7), 2246-2254.

Efrat, R. (2006) The evolution of bankruptcy stigma. Theoretical inquiries in Law, 7(2), 365-393.

European Commision (2013) Over-indebtedness of European households: updated mapping of the situation, nature and causes, effects and initiatives for alleviating its impact. European Commission: Directorate General Health and Consumers.

Friedman, M. (1957) A Theory of the Consumption Function. New Jersey: Princeton University Press.

Garðarsdóttir, R.B. \& Dittmar, H. (2012) The relationship of materialism to debt and financial well-being: The case of Iceland's perceived prosperity, Journal of Economic Psychology, 33(3), 471-481.

Gathergood, J. (2012) Self-control, financial literacy and consumer over-indebtedness. Journal of Economic Psychology, 33(3), 590-602.

Hung, A. Parker, A.M., \& Yoong, J. (2009) Defining and Measuring Financial Literacy. RAND Working Paper Series WR-708. SSRN: http://ssrn.com/abstract=1498674

Kahneman, D., \& Tversky, A. (1979) Prospect Theory: An Analysis of Decision Under Risk. Econometrica, 47, 263291.

Kamleitner, B., \& Kirchler, E. (2007) Consumer credit use: A process model and literature review. European Review of Applied Psychology, 57(4), 267-283.

Kempson, E. (2002) Over-indebtedness in Britain. London: Department of Trade and Industry.

Kilborn, J.J. (2011) Expert Recommendations and the Evolution of European Best Practices for the Treatment of Overindebtedness, 1984-2010. Deventer: Kluwer.

Lascelles, D., \& Mendelson, S. (2012) Microfinance Banana Skins 2012. The CSFI survey of microfinance risk. London: Centre for the Study of Financial Innovation.

Lea, S. E. G., Webley, P., \& Walker, C. M. (1995) Psychological factors in consumer debt: Money-management, economic socialization, and credit use. Journal of Economic Psychology, 16, 681-701.

Loewenstein, G., O'Donoghue, T., \& Rabin, M. (2003) Projection bias in predicting future utility. The Quarterly Journal of Economics, 118 (4), 1209-48.

Lyons, A. C. \& J. Fisher (2006) Gender Differences in Debt Repayment Problems after Divorce. Journal of Consumer Affairs, 40(2), 324-346.

Martín, A. S., \& García, B. M. (2016) Lending calling. Recession by over-indebtedness: Description and specific features of the Spanish case. Panoeconomicus, 63(2), 195-210.

Ortega y Gasset, J. (1961) Meditations on Quixote. University of Illinois Press. 
Porter, K. (2012) The Damage of Debt. Washington \& Lee Law Review, 69(2), 979-1022.

Schicks, J. (2014) Over-indebtedness in Microfinance-an empirical analysis of related factors on the borrower level. World Development, 54, 301-324.

Serrano-Cinca, C., Fuertes-Callén, Y., Gutiérrez-Nieto, B., \& Cuellar-Fernández, B. (2014) Path modelling to bankruptcy: causes and symptoms of the banking crisis. Applied Economics, 46(31), 3798-3811.

Shefrin, H. M., \& Thaler, R. H. (1988) The behavioral life-cycle hypothesis. Economic Inquiry, 26(4), 609-643.

Shiller, R. (1995) Conversation, Information and Herd Behaviour. American Economic Review, 85, 181-185.

Simon, H. A. (1956) Rational choice and the structure of the environment. Psychological Review, 63(2), 129.

Tokunaga, H. (1993). The use and abuse of consumer credit: Application of psychological theory and research. Journal of Economic Psychology, 14(2), 285-316.

Townley-Jones, M., Griffiths, M., Bryant, M. (2008) Chronic consumer debtors: the need for specific intervention. International Journal of Consumer Studies 32(3), 204-210. 


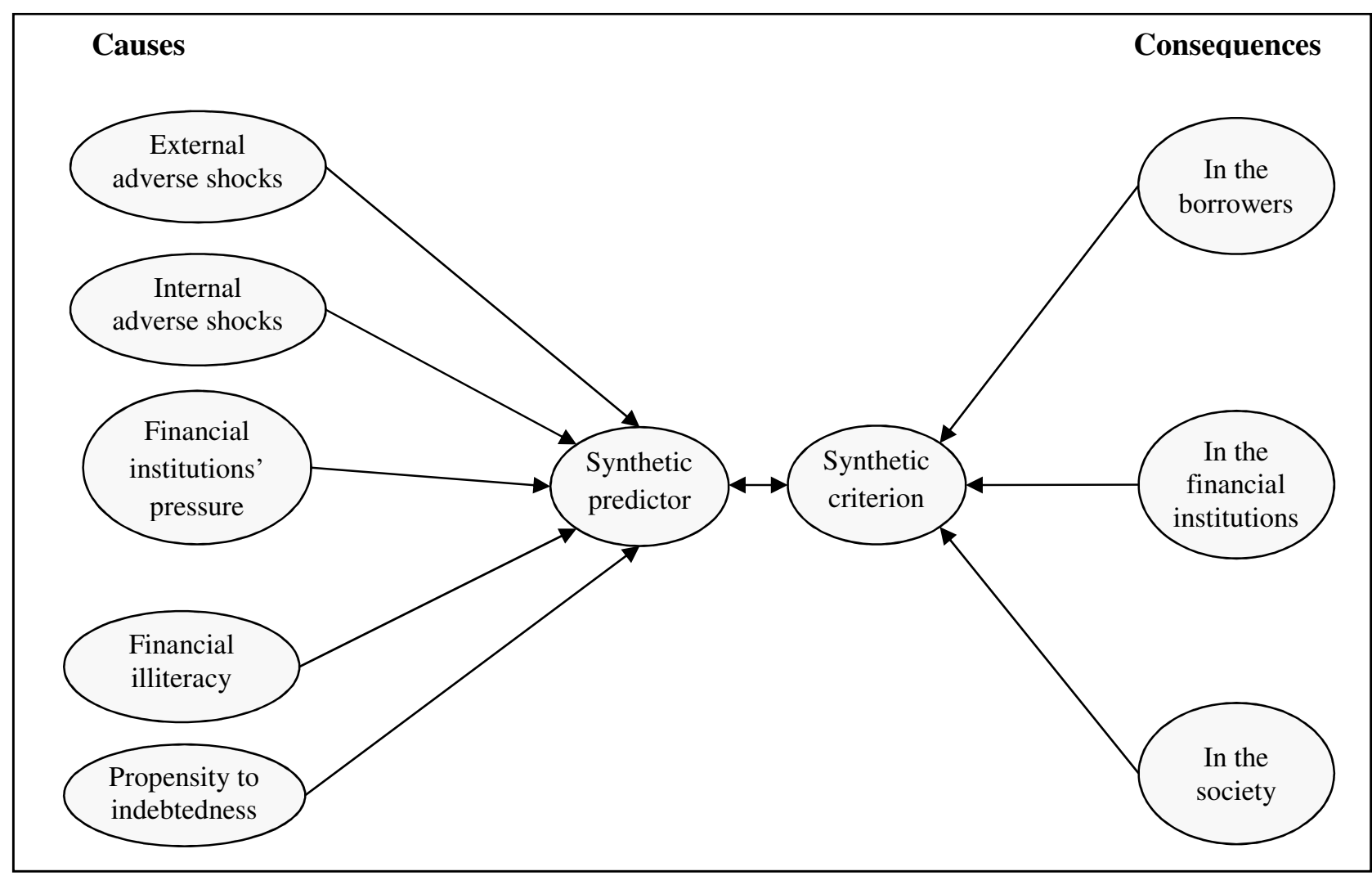

Figure 1. Illustration of the first function in a canonical correlation analysis with five predictors causes- and three criterion variables -consequences-. 


\begin{tabular}{|c|c|c|}
\hline & Variable & Definition \\
\hline \multirow{3}{*}{$\begin{array}{r}\text { External } \\
\text { adverse shocks }\end{array}$} & ShokExt-1 & Economic crisis \\
\hline & ShokExt-2 & Country financial unbalances \\
\hline & ShokExt-3 & Country unemployment \\
\hline \multirow{3}{*}{$\begin{array}{r}\text { Internal } \\
\text { adverse shocks }\end{array}$} & ShokInt-1 & Lowered income due to negative personal circumstances, such as divorce or illness \\
\hline & ShokInt-2 & Unexpected expenses in car, house, children \\
\hline & ShokInt-3 & Loss of job or bad evolution of own business \\
\hline \multirow{3}{*}{$\begin{array}{r}\text { Financial } \\
\text { institutions } \\
\text { pressure }\end{array}$} & PresBank-1 & Financial institutions pressure for loan allocation \\
\hline & PresBank-2 & Financial institutions pressure for growing \\
\hline & PresBank-3 & Loan officers pressure to sell financial products \\
\hline \multirow{3}{*}{$\begin{array}{r}\text { Financial } \\
\text { illiteracy }\end{array}$} & Literacy-1 & Borrower's low financial literacy \\
\hline & Literacy-2 & Borrower's low financial management skills \\
\hline & Literacy-3 & Borrower's lack of experience in financial issues \\
\hline \multirow{6}{*}{$\begin{array}{l}\text { Propensity to } \\
\text { indebtedness }\end{array}$} & ProDebt-1 & Borrower's materialism \\
\hline & ProDebt-2 & Borrower's attitude towards lending risk \\
\hline & ProDebt-3 & Borrower's tendency to imitate others \\
\hline & ProDebt-4 & Society's materialism \\
\hline & ProDebt-5 & Social support for debt, that is now considered acceptable \\
\hline & ProDebt-6 & Society encourages to have goods, to own a business or to be successful \\
\hline \multirow{6}{*}{$\begin{array}{r}\text { Borrower } \\
\text { material and } \\
\text { psychological } \\
\text { consequences }\end{array}$} & BorCon-1 & Deterioration of basic daily aspects such as diet, clothes or utility consumption \\
\hline & BorCon-2 & Borrower higher workload, overtime or the need to work when being ill \\
\hline & BorCon-3 & Drop in the borrower's standard of living \\
\hline & BorCon-4 & Deterioration in the borrower's mental health \\
\hline & BorCon-5 & Deterioration in the borrower's welfare \\
\hline & BorCon-6 & Lower borrower's self-esteem \\
\hline \multirow{6}{*}{$\begin{array}{r}\text { Lender } \\
\text { financial and } \\
\text { intangible } \\
\text { consequences }\end{array}$} & LendCon-1 & Deterioration in financial institutions solvency \\
\hline & LendCon-2 & Higher costs borne by financial institutions due to write-offs \\
\hline & LendCon-3 & Drop in loan demand \\
\hline & LendCon-4 & Loss of reputation in financial institutions \\
\hline & LendCon-5 & Financial industry is not doing its job well any more \\
\hline & LendCon-6 & Lack of motivation of banking employees and deterioration in the job environment \\
\hline \multirow{6}{*}{$\begin{array}{r}\text { Society } \\
\text { economic and } \\
\text { cohesion } \\
\text { consequences }\end{array}$} & SocCon-1 & Poverty growth \\
\hline & SocCon-2 & Higher costs of public services (health, labor, social protection, or public security) \\
\hline & SocCon-3 & Economic decline, implying less income for public bodies \\
\hline & SocCon-4 & Lowered social cohesion and social ties eroded \\
\hline & SocCon-5 & Loss of trust in the financial industry \\
\hline & SocCon-6 & Credit crunch, even for solvent customers \\
\hline
\end{tabular}

Table 1. Variables employed and their definition 


\begin{tabular}{|c|c|c|c|c|c|c|}
\hline & \multirow[t]{2}{*}{ Variable } & \multicolumn{2}{|c|}{$\begin{array}{l}\text { Experts } \\
(N=61)\end{array}$} & \multicolumn{2}{|c|}{$\begin{array}{l}\text { Individuals } \\
(N=61)\end{array}$} & \multirow[t]{2}{*}{ T-test, sig } \\
\hline & & Mean & St dev & Mean & St dev & \\
\hline \multirow[t]{3}{*}{ External adverse shocks } & ShokExt-1 & 3.56 & 1.89 & 6.03 & 1.63 & $7.734^{* * * *}$ \\
\hline & ShokExt-2 & 3.74 & 1.87 & 6.03 & 1.49 & $7.489^{* * *}$ \\
\hline & ShokExt-3 & 4.46 & 2.01 & 5.93 & 1.76 & $4.31^{* * *}$ \\
\hline \multirow[t]{3}{*}{ Internal adverse shocks } & ShokInt-1 & 4.46 & 1.78 & 3.90 & 2.23 & -1.522 \\
\hline & ShokInt-2 & 3.84 & 1.79 & 3.51 & 2.10 & -0.927 \\
\hline & ShokInt-3 & 5.02 & 1.75 & 5.74 & 1.84 & $2.219^{* *}$ \\
\hline \multirow[t]{3}{*}{ Financial institutions' pressure } & PresBank-1 & 4.10 & 1.87 & 5.82 & 1.49 & $5.628^{* * *}$ \\
\hline & PresBank-2 & 4.97 & 1.79 & 5.46 & 1.86 & 1.489 \\
\hline & PresBank-3 & 5.21 & 1.58 & 5.23 & 2.00 & 0.05 \\
\hline \multirow[t]{3}{*}{ Financial illiteracy } & Literacy-1 & 5.39 & 1.67 & 4.80 & 2.02 & $-1.759^{*}$ \\
\hline & Literacy-2 & 5.07 & 1.60 & 4.05 & 2.25 & $-2.871^{* * *}$ \\
\hline & Literacy-3 & 5.18 & 1.55 & 4.54 & 2.28 & $-1.807^{*}$ \\
\hline \multirow[t]{6}{*}{ Propensity to indebtedness } & ProDebt-1 & 4.62 & 1.65 & 4.25 & 2.17 & -1.081 \\
\hline & ProDebt-2 & 5.56 & 1.51 & 5.25 & 1.89 & -1.004 \\
\hline & ProDebt-3 & 4.72 & 1.80 & 4.38 & 2.07 & -0.979 \\
\hline & ProDebt-4 & 4.95 & 1.79 & 4.75 & 2.05 & -0.565 \\
\hline & ProDebt-5 & 4.72 & 1.76 & 4.77 & 2.07 & 0.141 \\
\hline & ProDebt-6 & 5.25 & 1.61 & 4.00 & 2.17 & $-3.604^{* * * *}$ \\
\hline \multirow{6}{*}{$\begin{array}{r}\text { Borrower material } \\
\text { and psychological consequences }\end{array}$} & BorCon-1 & 4.31 & 1.72 & 5.18 & 2.10 & $2.5^{* * * 3 *}$ \\
\hline & BorCon-2 & 4.92 & 1.44 & 4.48 & 2.26 & -1.292 \\
\hline & BorCon-3 & 5.44 & 1.52 & 5.52 & 1.92 & 0.261 \\
\hline & BorCon-4 & 5.18 & 1.60 & 4.30 & 2.39 & $-2.405^{* *}$ \\
\hline & BorCon-5 & 5.87 & 1.32 & 5.31 & 2.02 & $-1.802^{*}$ \\
\hline & BorCon-6 & 4.85 & 1.45 & 4.41 & 2.34 & -1.256 \\
\hline \multirow[t]{6}{*}{ Lender financial and intangible consequences } & LendCon-1 & 4.67 & 1.69 & 4.26 & 2.37 & -1.099 \\
\hline & LendCon-2 & 5.08 & 1.63 & 4.90 & 2.35 & -0.493 \\
\hline & LendCon-3 & 4.64 & 1.69 & 4.11 & 2.46 & -1.373 \\
\hline & LendCon-4 & 4.79 & 1.68 & 4.26 & 2.42 & -1.389 \\
\hline & LendCon-5 & 5.48 & 1.70 & 4.74 & 2.21 & $-2.070^{* *}$ \\
\hline & LendCon-6 & 4.48 & 1.84 & 4.08 & 2.25 & -1.058 \\
\hline \multirow[t]{6}{*}{ Society economic and cohesion consequences } & SocCon-1 & 5.75 & 1.35 & 5.98 & 1.82 & 0.791 \\
\hline & SocCon-2 & 4.54 & 1.86 & 4.85 & 2.26 & 0.832 \\
\hline & SocCon-3 & 4.95 & 1.71 & 5.25 & 1.78 & 0.935 \\
\hline & SocCon-4 & 4.90 & 1.62 & 4.90 & 2.00 & 0.0 \\
\hline & SocCon-5 & 5.52 & 1.48 & 4.97 & 2.14 & $-1.671^{*}$ \\
\hline & SocCon-6 & 5.03 & 1.85 & 5.25 & 2.01 & 0.608 \\
\hline
\end{tabular}

Note: ${ }^{*} \mathrm{p}<0.05 ;{ }^{* *} \mathrm{p}<0.01 ;{ }^{* * *} \mathrm{p}<0.001$.

Table 2. Exploratory study. The last column shows the results of a means test testing differences between experts and individuals. 


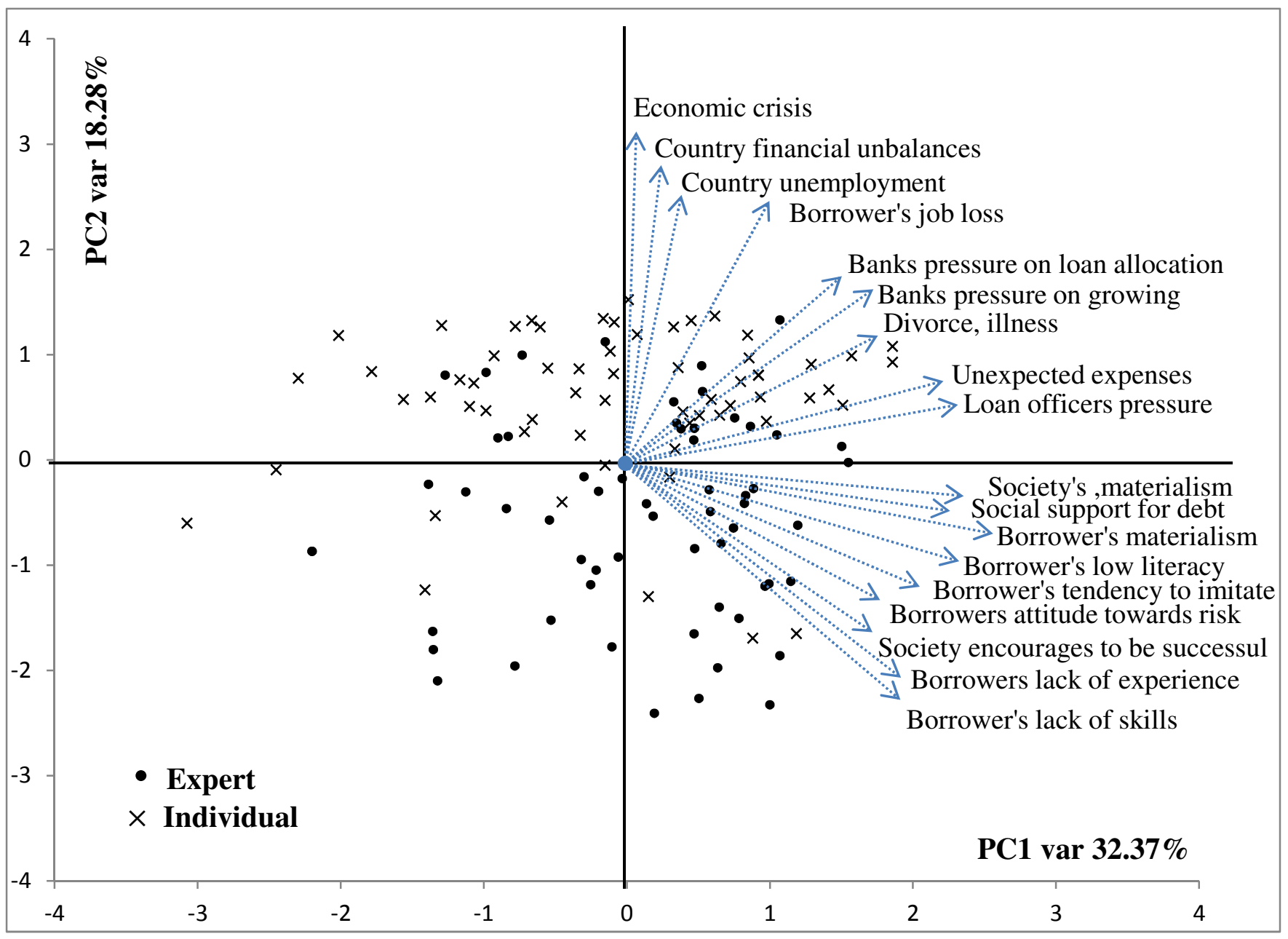

Economic crisis Country unbalances Country unemployment Loss of job Lowered income Unexpected expenses Banks pressure grow Loan officers pressure Banks pressure loan Low financial literacy

Low financial skills

Lack of experience Society's materialism Social support for debt

Society encourages

Tendency to imitate Attitude towards risk

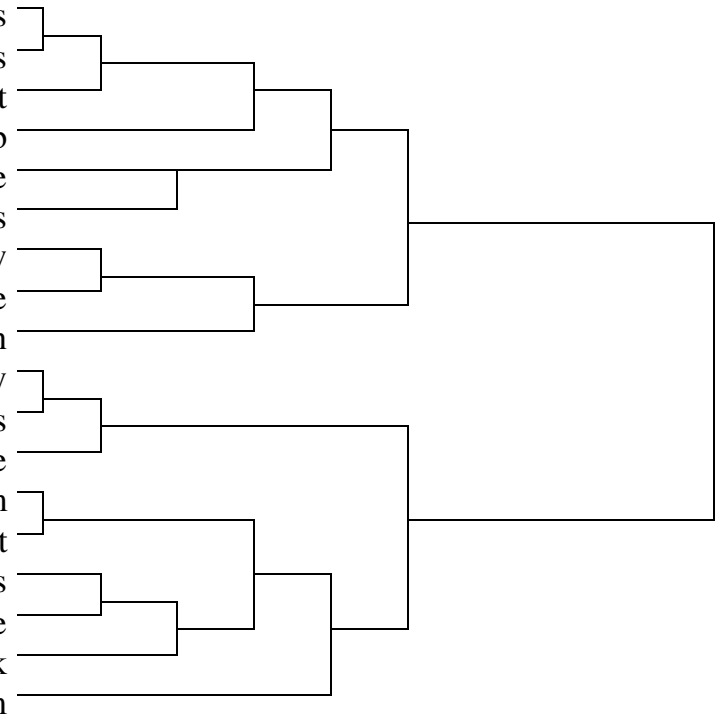

Figure 2. Results of Biplot-Principal Component Analysis, and Cluster Analysis for causes 


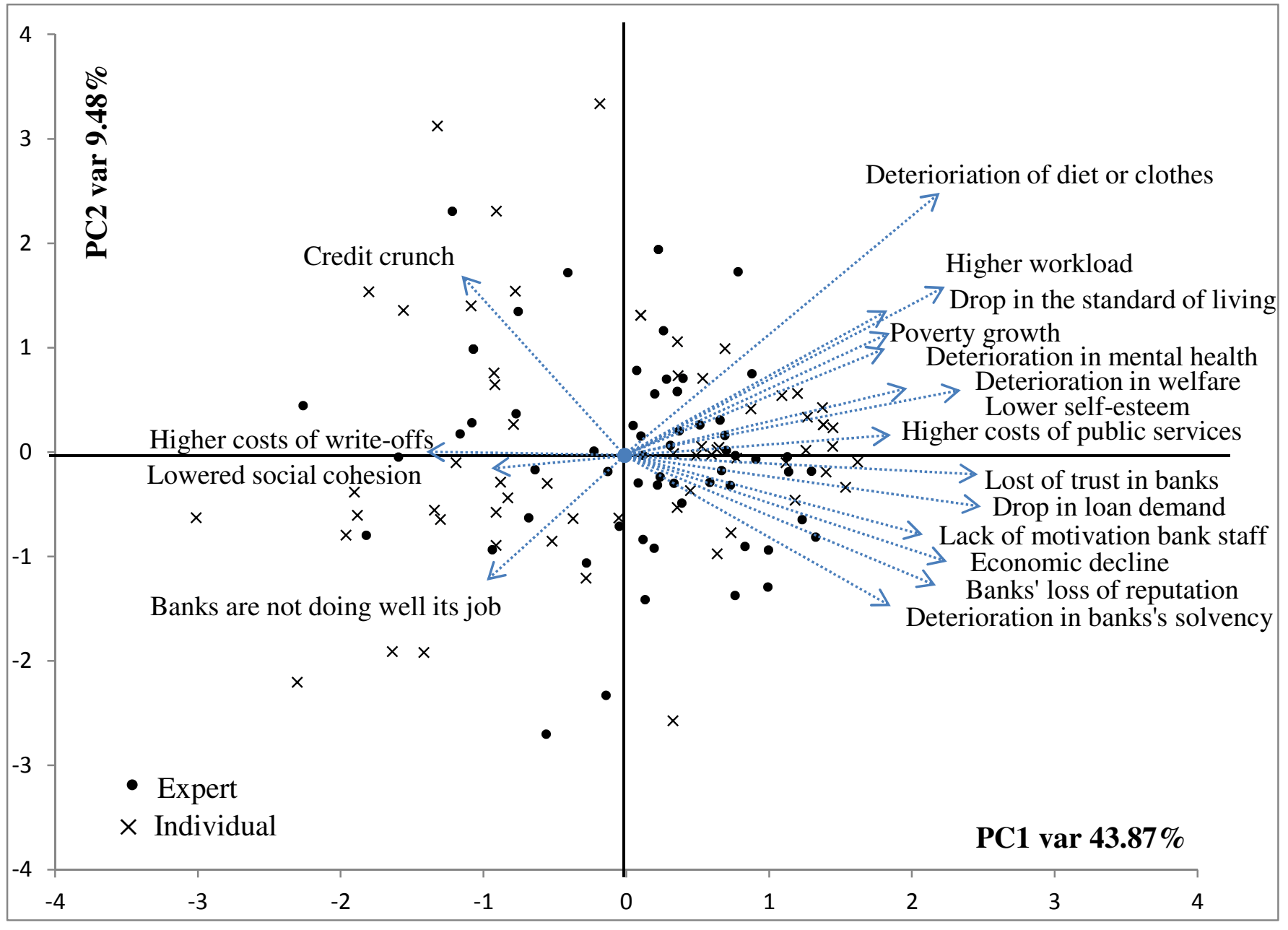

Borrower's mental health

Borrower's self-esteem

Borrower's welfare

Higher workload

Deterioration of basic daily

Drop standard of living

Higher costs of public services

Loss of trust in banks

Credit crunch

Poverty growth

Economic decline

Lowered social cohesion

Deterioration of banks solvency

Loss of reputation in banks

Motivation loss bank employees

Drop in loan demand

Higher costs borne by banks

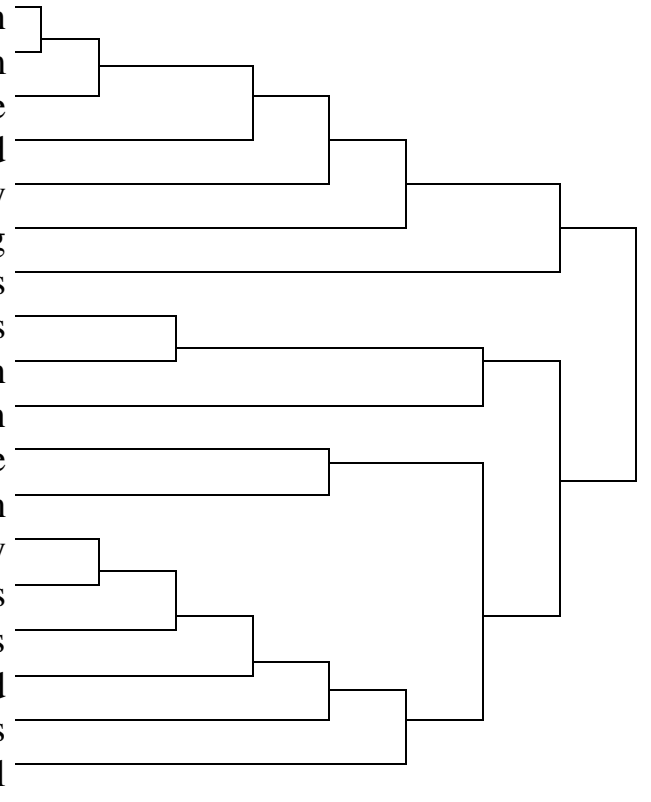

Figure 3. Results of Biplot-Principal Component Analysis, and Cluster Analysis for consequences 
Function 1

\begin{tabular}{|c|c|c|c|c|c|c|c|}
\hline & & & & & & & \\
\hline & Coef. & $r_{s}$ & $r_{s}^{2}(\%)$ & Coef. & $\boldsymbol{r}_{s}$ & $r_{s}^{2}(\%)$ & $h^{2}(\%)$ \\
\hline \multicolumn{8}{|l|}{ External adverse shocks } \\
\hline ShokExt-1 & 0.310 & 0.635 & $40.37 \%$ & -0.601 & -0.280 & $7.86 \%$ & $48.24 \%$ \\
\hline ShokExt-2 & 0.046 & 0.437 & $19.12 \%$ & 0.958 & 0.137 & $1.88 \%$ & $21.00 \%$ \\
\hline ShokExt-3 & 0.412 & 0.596 & $35.57 \%$ & -0.514 & -0.431 & $18.61 \%$ & $54.18 \%$ \\
\hline \multicolumn{8}{|l|}{ Internal adverse shocks } \\
\hline ShokInt-1 & -0.233 & -0.119 & $1.41 \%$ & -0.119 & -0.388 & $15.08 \%$ & $16.50 \%$ \\
\hline ShokInt-2 & -0.238 & -0.114 & $1.29 \%$ & 0.076 & -0.342 & $11.71 \%$ & $13.00 \%$ \\
\hline ShokInt-3 & 0.068 & 0.234 & $5.47 \%$ & -0.019 & -0.387 & $14.95 \%$ & $20.42 \%$ \\
\hline \multicolumn{8}{|l|}{ Banks' pressure } \\
\hline PresBank-1 & 0.291 & 0.200 & $3.99 \%$ & 0.117 & -0.015 & $0.02 \%$ & $4.01 \%$ \\
\hline PresBank-2 & -0.050 & -0.137 & $1.86 \%$ & 0.170 & -0.047 & $0.22 \%$ & $2.09 \%$ \\
\hline PresBank-3 & -0.714 & -0.455 & $20.66 \%$ & -0.582 & -0.380 & $14.43 \%$ & $35.09 \%$ \\
\hline \multicolumn{8}{|l|}{ Lack of financial literacy } \\
\hline Literacy-1 & 0.216 & -0.190 & $3.59 \%$ & 0.237 & -0.176 & $3.09 \%$ & $6.68 \%$ \\
\hline Literacy-2 & -0.252 & -0.358 & $12.81 \%$ & 0.080 & -0.266 & $7.08 \%$ & $19.89 \%$ \\
\hline Literacy-3 & 0.026 & -0.324 & $10.51 \%$ & -0.356 & -0.305 & $9.31 \%$ & $19.82 \%$ \\
\hline \multicolumn{8}{|l|}{ Propensity to indebtedness } \\
\hline ProDebt-1 & -0.116 & 0.004 & $0.00 \%$ & 0.029 & -0.230 & $5.27 \%$ & $5.27 \%$ \\
\hline ProDebt-2 & 0.150 & -0.082 & $0.67 \%$ & 0.246 & -0.055 & $0.30 \%$ & $0.98 \%$ \\
\hline ProDebt-3 & 0.066 & -0.088 & $0.77 \%$ & 0.116 & -0.348 & $12.13 \%$ & $12.90 \%$ \\
\hline ProDebt-4 & 0.277 & 0.114 & $1.31 \%$ & -0.399 & -0.450 & $20.21 \%$ & $21.52 \%$ \\
\hline ProDebt-5 & 0.161 & 0.125 & $1.55 \%$ & -0.015 & -0.327 & $10.70 \%$ & $12.26 \%$ \\
\hline ProDebt-6 & -0.013 & -0.200 & $4.00 \%$ & -0.198 & -0.355 & $12.59 \%$ & $16.59 \%$ \\
\hline \multicolumn{8}{|l|}{ Borrower consequences } \\
\hline BorCon-1 & 0.585 & 0.338 & $11.43 \%$ & 0.262 & -0.107 & $1.13 \%$ & $12.56 \%$ \\
\hline BorCon-2 & -0.348 & -0.238 & $5.66 \%$ & -0.056 & -0.462 & $21.31 \%$ & $26.97 \%$ \\
\hline BorCon-3 & 0.385 & 0.130 & $1.68 \%$ & -0.449 & -0.437 & $19.07 \%$ & $20.75 \%$ \\
\hline BorCon-4 & -0.793 & -0.322 & $10.37 \%$ & 0.349 & -0.331 & $10.99 \%$ & $21.36 \%$ \\
\hline BorCon-5 & -0.040 & -0.154 & $2.36 \%$ & 0.233 & -0.319 & $10.15 \%$ & $12.51 \%$ \\
\hline BorCon-6 & 0.189 & -0.198 & $3.91 \%$ & -0.559 & -0.580 & $33.68 \%$ & $37.59 \%$ \\
\hline \multicolumn{8}{|l|}{ Lender consequences } \\
\hline LendCon-1 & -0.382 & -0.196 & $3.82 \%$ & 0.410 & -0.466 & $21.71 \%$ & $25.53 \%$ \\
\hline LendCon-2 & 0.120 & 0.025 & $0.06 \%$ & 0.048 & -0.291 & $8.44 \%$ & $8.51 \%$ \\
\hline LendCon-3 & 0.069 & -0.125 & $1.55 \%$ & -0.184 & -0.493 & $24.33 \%$ & $25.88 \%$ \\
\hline LendCon-4 & 0.390 & -0.187 & $3.48 \%$ & -0.768 & -0.715 & $51.14 \%$ & $54.62 \%$ \\
\hline LendCon-5 & -0.268 & -0.247 & $6.11 \%$ & 0.217 & -0.295 & $8.70 \%$ & $14.82 \%$ \\
\hline LendCon-6 & 0.157 & -0.210 & $4.42 \%$ & -0.061 & -0.559 & $31.21 \%$ & $35.63 \%$ \\
\hline \multicolumn{8}{|l|}{ Society consequences } \\
\hline SocCon-1 & 0.545 & 0.327 & $10.70 \%$ & -0.048 & -0.368 & $13.54 \%$ & $24.24 \%$ \\
\hline SocCon-2 & 0.058 & 0.108 & $1.17 \%$ & -0.047 & -0.337 & $11.33 \%$ & $12.50 \%$ \\
\hline SocCon-3 & 0.203 & 0.015 & $0.02 \%$ & -0.463 & -0.633 & $40.04 \%$ & $40.06 \%$ \\
\hline SocCon-4 & -0.227 & -0.190 & $3.61 \%$ & 0.161 & -0.475 & $22.52 \%$ & $26.13 \%$ \\
\hline SocCon-5 & -0.371 & -0.368 & $13.56 \%$ & 0.010 & -0.568 & $32.22 \%$ & $45.78 \%$ \\
\hline SocCon-6 & -0.210 & -0.233 & $5.43 \%$ & -0.041 & -0.536 & $28.73 \%$ & $34.16 \%$ \\
\hline$R_{c}^{2}$ & & & $60.18 \%$ & & & & $50.30 \%$ \\
\hline
\end{tabular}

Table 3. Canonical solution for causes and consequences of over-indebtedness, for Functions 1 and 2. Coef $=$ standardized canonical function coefficient; $\boldsymbol{r}_{\boldsymbol{s}}=$ structure coefficient; $\boldsymbol{r}_{\boldsymbol{s}}^{2}=$ squared structure coefficient; $h^{2}=$ communality coefficient. 